\title{
PENERAPAN TEKNIK MELEMPAR BOLA DALAM MENINGKATKAN MOTIVASI DAN HASIL BELAJAR PKN PESERTA DIDIK SMK NEGERI 1 SAKRA TAHUN PELAJARAN 2018/2019
}

\author{
Ahmad Farijan \\ SMK Negeri 1 Sakra \\ ahmadfarijan@smkn1sakra.sch.id
}

\begin{abstract}
The subject of this research is the students of class X. a of SMK Negeri 1 Sakra with a total of 33 students. This type of research is a classroom action research (CAR) using quantitative and qualitative approaches. Research activities use 2 cycles. Based on the results of research analysis obtained data on student motivation in the first cycle reached 69\% in the high category and in the second cycle reached 80\% in the very bigh category. Then the evaluation results obtained in the first cycle were 9 students who were incomplete out of 33 total number of students, while the percentage of classical learning completeness achieved $70 \%$ of the results of the second cycle evaluation were 4 students who were declared incomplete out of the total 33 students, as for the percentage of mastery learning classical achieved $88 \%$, so the research results obtained are increasing from each cycle. So the evaluation results show that the application of the Ball Throwing Technique can be well received
\end{abstract}

Keywords: Ball Throwing Technique, Motivation, Learning Outcomes, PKn

\begin{abstract}
Abstrak : Anak Subjek Penelitian ini adalah sisw kelas X.a SMK Negeri 1 Sakra yang berjumlah 33 siswa. Jenis penelitian ini merupakan penelitian tindakan kelas (PTK) menggunakan pendekatan kuantitatif dan kualitatif. Kegiatan penelitian menggunakan 2 siklus. Berdasarkan hasil analisis penelitian diperoleh data mengenai motivasi belajar siswa pada siklus I mencapai 69\% pada kategori tinggi dan pada siklus II mencapai $80 \%$ pada kategori sangat tinggi. Kemudian didapatkan hasil evaluasi pada siklus I adalah 9 orang peserta didik yang belum tuntas dari 33 jumlah keseluruhan peserta didik, adapun persentase ketuntasan belajar klasikal yang dicapai $70 \%$ hasil evaluasi siklus II adalah 4 orang peserta didik yang dinyatakan belum tuntas dari 33 jumlah keseluruhan peserta didik, adapun persentase ketuntasan belajar klasikal yang dicapai $88 \%$, jadi hasil penelitian yang didapatkan semakin meningkat dari tiap siklus. Jadi hasil evaluasi menunjukkan bahwa penerapan Teknik Melempar Bola dapat diterima dengan baik
\end{abstract}

Kata Kunci : Teknik Melempar Bola, Motivasi, Hasil Belajar, PKn 


\section{PENDAHULUAN}

Masalah pendidikan yang utama di Indonesia adalah sangat rendahnya mutu pendidikan hampir setiap jenjang pendidikan (SD, SMP, dan SMA). Setelah dilakukan usaha perbaikan dalam bidang pendidikan, semakin disadari bahwa masih banyak kekurangan kekurangan yang mendasar. Salah satunya kekurangan tersebut adalah terletak pada proses belajar mengajar yang melibatkan siswa dan pendidik. Pandangan tentang pendidikan masih berorientasi pada seperangkat pengetahuan yang erupa fakta-fakta, definisi, dan konsep yang harus dihafal oleh peserta didik tanpa menghiraukan proses pembelajaran ${ }^{1}$.

Peningkatan mutu pendidikan merupakan prioritas utama dalam penyelenggaraan pendidikan. Pemerintah melalui Kementrian Pendidikan Nasional telah berupaya meningkatkan mutu pendidikan melalui penyelenggaraan pendidikan yang berkualitas, seperti penyempurnaan kurikulum, pengadaan fasilitas belajar di sekolah dan memperbaiki sistem pembelajaran di kelas. Pemerintah daerah sebagai perpanjang tangan pemerintah pusat juga telah melakukan usaha untuk mendukung upaya upaya yang telah dilakukan oleh pemerintah tersebut, diantaranya dengan melakukan perbaikan sistem pendidikan di daerah, penyempurnaan kurikulum, peningkatan profesionalisme guru, khususnya mata pelajaran Pkn, pengadaan buku mata pelajaran, perbaikan sarana dan prasarana serta peningkatan kemampuan mengajar guru dengan menerapkan variasi model-model pembelajaran yang menuntut siswa belajar lebih aktif.

Model pembelajaran yang menjadi prioritas utama untuk diperbaiki saat ini adalah strategi pembelajaran yang masih menekankan pada aspek hafalan atau ingatan semata. Padahal dalam proses pembelajaran Pkn sangat di butuhkan strategi pembelajaran atau model belajar yang sesuai karakter materi pembelajaran Pkn yang menekankan pada proses atau bagaimana seharusnya belajar. Penerapan metode pembelajaran oleh pendidik dalam pembelajaran Pkn terkadang tidak bisa maksimal. Hal ini terlihat dari hasil atau prestasi belajar peserta didik yang masih belum maksimal juga.

${ }^{1}$ Depdiknas, Kegiatan Belajar Mengajar. Jakarta Pusat Kurikulum Balitbang Depdiknas. 2002. 
Berdasarkan pengamatan yang dilakukan penulis, bahwa tidak semua pendidik menerapkan strategi, metode dan media yang tepat dan bervariasi. Pembelajaran yang diterapkan oleh pendidik di dominasi dengan ceramah dan guru kurang merangsang pemikiran peserta didik, sehingga mengakibatkan semangat belajar peserta didik menjadi rendah. Rendahnya semangat belajar peserta didik mempengaruhi daya pemahaman peserta didik dalam belajar.

Upaya untuk mengatasi permasalahan di atas, pendidik harus melakukan langkah perbaikan terhadap aspek-aspek pembelajaran yang menjadi penyebab rendahnya hasil belajar peserta didik. Untuk meningkatkan hasil belajar peserta didik pendidik harus mampu memperbaiki kegiatan pembelajaran dengan menerapkan multi metode dan multi media. Salah satu upaya penyelesaian untuk meningkatkan hasil belajar peserta didik dalam pembelajaran Pkn yaitu strategi atau teknik melempar bola. Penerapan teknik pembelajaran tersebut diharapkan hasil belajar peserta didik tinggi sehingga hasil belajar peserta didik di SMK Negeri 1 Sakra akan meningkat.

\section{TINJAUAN PUSTAKA}

\section{Motivasi Belajar}

Belajar adalah perubahan tingkah laku secara reatif permanen dan secara potensial terjadi sebagai hasil dari praktik atau pengamatan yang dilandasi tujuan untuk mencapai tujuan tertentu ${ }^{2}$. Motivasi belajar timbul karena faktor intrinsik, berupa hasrat dan keinginan berhasil dan dorongan kebutuhan belajar, harapan akan cita cita. Sedangkan faktor intrinsiknya adalah adanya penghargaan, lingkungan belajar yang kondusif, dan kegiatan belajar yang menarik

\section{Pengertian Hasil Belajar}

Belajar adalah suatu proses usaha yang dilakukan seseorang untuk memperoleh suatu perubahan tingkah laku yang baru secara keseluruhan, sebagai hasil pengalaman sendiri dalam interaksi dengan lingkungannya ${ }^{3}$. Belajar adalah suat pertumbuhan atau perubahan dalam diri seseorang yang dinyatakan dalam cara cara

${ }^{2}$ Hamzah, Teori motivasi dan Pengukurannya (Analisi di Bidang Pendidian) Jakarta: PT. Bumi Aksara. 2009. Hal. 23.

${ }^{3}$ Hamalik, Oemar, Pengembangan Kurikulum (dasar Dasar dan pengembangannya) Bandung CV Mandar Maju. 2001. Hal.17 
bertingkah laku yang baru berkat pengalaman latihan ${ }^{4}$. Hasil belajar didefinisikan sebagai suatu hasil yang diharapkan dari pembelajaran yang telah diterapkan dalam rumusan perilaku tertentu sebagai akibat dari proses pembelajaran.

Dari pengertian hasil belajar yang telah dikemukakan oleh para ahli maka intinya adalah "perubahan" karena itu seorang yang melakukan aktivitas dan memperoleh perubahan dalam dirinya dengan memperoleh pengalaman baru, maka individu itu dikatakan telah belajar.

Perubahan perubahan tingkah yang terjadi dalam hasil belajar memiliki ciri ciri: 1) perubahan terjadi secara sadar; 2) perubahan dalam belajar bersifat fungsional; 3) perubahan bersifat positif dan aktif; 4) perubahan bukan bersifat sementara; 5) perubahan bersifat bertujuan dan terarah; 6) mencakup seluruh aspek tingkah laku;

Jadi hasil belajar Pkn peserta didik dimaksud dalam jurnal ini adalah pengetahuan yang dicapai peserta didik pada mata pelajaran Pkn setelah mengalami proses pembelajaran di sekolah dari hasil tes atau ujian yang diberikan setelah melewati proses belajar.

\section{Teknik Melempar Bola}

Strategi pembelajaran merupakan tindakan nyata dari pendidik atau praktik pendidik melaksanakan pengajaran melalui cara tertentu yang di nilai lebih efektif dan efisien, serat politik atau taktik (langkah langkah sistematik) yang digunakan pendidik pada saat proses pembelajaran.

Tahap Pembelajaran (1) pembukaan: dalam pembukaan ada tiga bagian yaitu penyampaian tujuan pembelajaran, apersepsi, dan motivasi; (2) Inti; Dalam tahapan pembelajaran dilakukan tahapan sebagai berikut: a, siswa diberikan informasi singkat tantang strategi pembelajaran yang akan diberikan; b. siswa di bagi menjadi beberapa kelompok; c. siswa bekerja dengan kelompok dengan berpedoman pada kertas kerja; d. guru melakukan bimbingan kepada kelompok siswa yang mengalami kesulitan sambil melakukan penilaian; e. validasi hasil kerja kelompok siswa 3) Penutup; a. kesimpulan; b. Quis (refleksi) c. pemberian penghargaan; d. pemberian tugas 5 .

${ }^{4}$ Hamalik, Oemar,. Proses Belajar Mengajar, Jakarta: Bumi Aksara 1983: hal 28

${ }^{5}$ Lia, A. Mempraktekkan Cooverative Learning di Ruang Ruang Kelas. Jakarta: PT Gramedia Widia Sarana. 2002. 
Teknik Melempar bola yakni ${ }^{6}$

1. Teknik melempar Bola Berputar yang meliputi tiga tahapan yaitu

a. Membentuk kelompok

1) Siswa dikelompokkan (dibagi) sesuai dengan jumlah uraian materi

2) Setiap kelompok menyiapkan satu atau dua orang sebagai pembicara (dipilih secara acak)

b. Mengkaji Permasalahan (materi)

1) Setiap kelompok membahas setiap permasalahan (materi)

2) Setiap kelompok menyiapkan dua pertanyaan untuk diajukan kepada kelompok lain

3) Memberikan Kesimpulan

c. Presentasi (unjuk Kerja)

1) Setiap kelompok menuliskan pertanyaan dalam satu lembar kertas

2) Kertas pertanyaan dibentuk bundar seperti bola kertas dengan menuliskan nomor urut

3) Bola kertas dilemparkan kepada setiap kelompok sesuai perintah

4) Secara terurut setiap kelompok menjelaskan/menguraikan permasalahan (materi) diskusi terarah dengan panduan pembimbing

5) Setiap kelompok dalam menjawab pertanyaan akan dibantu oleh kelompok pendamping

6) Memberi kesimpulan

2. Teknik Melempar Bola Lurus, yang meliputi tiga tahapan pula yaitu:

a. Membentuk Kelompok

1) Siswa dikelompokkan (dibagi) sesuai jumlah uraian materi

2) Setiap kelompok menyiapkan satu atau dua orang sebagai pembicara (dipilih secara acak)

b. Mengkaji Permasalahan (materi)

1) Setiap kelompok membahas setiap permasalahan (materi)

2) Memberikan kesimpulan

3) Kelompok mengumpulkan hasil kerja kelompok kepada pembimbing

${ }^{6}$ Sudaryanti, Eni, Strategi Pembelajaran. Diktat Perkuliahan FKIP Universitas Mataram. 2007 hal: 24-27 
c. Presentasi

1) Setiap kelompok menuliskan pertanyaan dalam satu lembar kertas

2) Kertas pertanyaan dibentuk bundar seperti bola kertas dengan menuliskan nomor urut

3) Bola kertas dilemparkan yang siap untuk mempresentasikan hasil kelompoknya di depan kelas

4) Dengan arahan pembimbing, kelompok presentasi diberikan lembar tes yang berkaitan dengan materi untuk di jawab secara lisan dengan tenggang waktu yang ditentukan

5) Kelompok presentasi akan diberikan pin oleh pembimbing

6) Memberikan kesimpulan

\section{METODE PENELITIAN}

Jenis Penelitian Tindakan Kelas (PTK), karena penelitian ini dilakukan oleh guru atau peneliti di dalam kelas, dengan tujuan untuk memperbaiki kinerja guru. Penelitian Tindakan Kelas adalah penelitian yang dilakukan oleh guru atau peneliti di dalam kelas, dengan tujuan untuk memperbaiki kinerja guru sehingga hasil belajar siswa menjadi meningkat. Pendekatan yang digunakan dalam penelitian ini adalah pendekatan kualitatif dan kuantitatif. Pendekatan kualitatif adalah suatu pendekatan dimana data yang diperoleh berbentuk kalimat, kata atau gambar sedangkan pendekatan kuantitatif adalah pendekatan dimana data yang diperoleh berbentuk angka, atau data kualitatif yang diangkakan ${ }^{8}$.

Teknik pengumpulan data dalam pelaksanaan penelitian ini adalah sebagai berikut 1) Observasi, merupakan teknik menganalisis atau mengadakan pencatatan secara sistematis mengenai tingkah laku dengan melihat atau mengamati individu atau kelompok secara langsung. Penelitian ini, observasi digunakan untuk memperoleh data keterlaksanaan pembelajaran oleh guru dan siswa berdasarkan RPP; 2) Tes, merupakan teknik pengumpulan data yang berisi pertanyaan atau latihan serta alat lain yang digunakan untuk mengukur motivasi, keterampilan, pengetahuan, atau bakat

7 Aqib, Penelitian Tindakan Kelas, Bandung, Yrama Widya: 2009 hal: 26

${ }^{8}$ Swarsih Madya, Teori dan Praktik Penelitian Tindakan Kelas. Jakarta: Rineka Cipta; 2009. hal: 30 
yang dimiliki atau kelompok. Teknik tes ini digunakan untuk mengukur hasil belajar siswa setelah mengikuti pembelajaran.

\section{HASIL DAN PEMBAHASAN}

Penelitian Tindakan Kelas (PTK) ini dilakukan sebagai upaya untuk meningkatkan hasil belajar Pkn dengan menerapkan pembelajaran Teknik Melempar Bola.

1. Aktivitas Guru

Berdasarkan data hasil observasi tentang mengajar guru di kelas, pada siklus 1 menunjukkan bahwa aktivitas guru tergolong tinggi, hal ini ditemukan beberapa kekurangan dari guru saat menyampaikan materi pelajaran antara lain: guru kurang memberi motivasi kepada siswa sehingga dalam proses belajar mengajar banyak siswa yang kurang atusias dalam diskusi, kurangnya partisipasi siswa dalam menyimpulkan materi, kurang keberanian siswa dalam menyampaikan pendapat dan bertanya, dan guru terlalu memberikan bimbingan kepada siswa sehingga siswa bergantung pada guru.

Sementara pada siklus II ketercapaian skor aktivitas guru mengalami peningkatan dan masuk dalam kategori sangat tinggi. Hal ini disebabkan karena guru telah maksimal membimbing dan memfasilitasi siswa yang benar-benar membutuhkan bimbingan secara merata (tidak selalu yang pintar) serta memotivasi siswa dalam mengeluarkan pendapat dan menyimpulkan materi, aktivitas siswa selama mengikuti proses pembelajaran dengan menggunakan pembelajaran Teknik Melempar Bola sudah aktif. Dengan demikian dalam proses belajar mengajar siswa lebih aktif dan berpartisipasi lebih banyak.

\section{Motivasi Belajar siswa}

Berdasarkan hasil data analisis tentang motivasi belajar siswa diperoleh nilai rata-rata tingkat motivasi siswa pada siklus I mencapai 69\% yaitu antara 66-79\% pada kategori tinggi. Sementara pada siklus II nilai rata rata $80 \%$ yaitu antara 80 $100 \%$ pada kategori sangat tinggi.

Secara garis besar dapat di simpulkan bahwa tingkat motivasi siswa menggunakan Teknik Melempar Bola mengalami peningkatan, disebabkan karena perhatian siswa terhadap stimulus belajar sangat tinggi terhadap proses 
pembelajaran, serta dapat di wujudkan melalui beberapa cara seperti memberikan pujian, hadiah, melakukan pengulangan informasi yang berbeda dengan cara sebelumnya, memberikan stimulus belajar dalam bentuk lain sehingga siswa tidak bosan, dan gerakan tubuh sehingga siswa termotivasi untuk belajar.

3. Peningkatan Hasil belajar siswa

Siklus I menunjukkan bahwa nilai rata rata siswa 68,9 dengan persentase ketuntasan klasikal sebesar 73\% ini berarti pada siklus I ketuntasan belajar siswa belum tercapai sesuai dengan yang diharapkan. Hal ini proses belajar mengajar diantaranya yaitu kurang antusias siswa dalam menerima materi pelajaran, siswa juga kurang berani dalam mengeluarkan pendapat dan bertanya, kurangnya komunikasi dan kerjasama antar kelompok selama diskusi, serta guru kurang memotivasi siswa dan membimbing siswa yang benar-benar mengalami kesulitan dalam belajar, dan siswa kurang siap menerima materi pelajaran karena masih banyak siswa yang kurang mengerti dan tidak bertanya tentang kesulitan yang di hadapi.

Hasil refleksi siklus I mengisyaratkan perbaikan perbaikan tindakan selanjutnya. Adapun tindakan yang dilakukan untuk memperbaiki kekurangan dan kelemahan siklus 1 antara lain guru harus lebih mengaktifkan siswa terutama dalam bertanya dan diskusi serta guru juga harus benar-benar membimbing siswa yang mengalami kesulitan baik dalam belajar maupun berdiskusi dengan temannya. Dalam hal ini di tekankan peran guru sebagai pembimbing dan sebagai fasilitator dalam kegiatan belajar mengajar harus mampu melaksanakan tugasnya dengan baik, harus memberikan kesempatan yang maksimal kepada siswa untuk bertanya dan mengemukakan pendapatnya dengan bahasa sendiri, agar siswa benar-benar mereka sendiri yang menemukannya. Di samping itu juga guru harus memantau dan lebih memberi perhatian kepada siswa yang mengalami kesulitan dalam proses pembelajaran supaya siswa menjadi lebih aktif bertanya dan lebih berani mengutarakan pendapatnya. Dengan demikian siswa akan merasa diperhatikan dan termotivasi untuk mengetahui kegiatan pembelajaran sehingga proses pembelajaran menggunakan pembelajaran Teknik Melempar Bola ini benar-benar dilaksanakan secara optimal dan sempurna. 
Dengan mengacu pada pengalaman-pengalaman dan perlakuan siklus I, maka dilaksanakan tindakan pada siklus II. Proses belajar mengajar pada siklus II terlaksana dengan baik dari sebelumnya. Hal ini terbukti dengan tercapainya persentase ketuntasan klasikal sebesar 88\%, dari 33 siswa yang ikut dalam proses belajar mengajar yang tuntas sebanyak 29 siswa. Ini menunjukkan bahwa persentase klasikal yang ditetapkan dalam kriteria keberhasilan penelitian sudah tercapai.

Belajar dengan menggunakan pembelajaran Teknik Melempar Bola memiliki peranan siswa berperan aktif dan melibatkan segenap kemampuan yang dimiliki siswa sehingga motivasi dan hasil belajar siswa meningkat dengan baik. Sedangkan hasil observasi pembelajaran siklus II juga menunjukkan peningkatan.

\section{KESIMPULAN}

Berdasarkan hasil analisa data dan pembahasan, maka dapat di simpulkan bahwa penerapan pembelajaran Teknik melempar Bola pada mata pelajaran Pkn dapat meningkatkan hasil belajar siswa di SMK Negeri 1 Sakra Tahun Pelajaran 2018/2019. Yang dibuktikan dengan adanya hasil motivasi belajar siswa pada siklus I sebesar 69\% dan siklus II sebesar 80\% dimana persentase ketuntasan klasikal hasil belajar siswa siklus I sebesar 73\% dan siklus II sebesar 88\% jumlah ini sudah lebih tinggi dari standar ketuntasan klasikal sebesar 85\%

\section{SARAN}

1).Dalam proses belajar mengajar hendaknya menggunakan metode sesuai dengan materi yang akan disampaikan agar siswa tidak cepat merasa bosan dalam mengikuti pelajaran 2). Hasil penelitian ini diharapkan dapat digunakan sebagai bahan pertimbangan bagi guru dalam upaya meningkatkan motivasi dan penguasaan konsep belajar siswa, khususnya pada mata pelajaran Pkn; 3) Perlu dilakukan penelitian lebih lanjut mengenai penerapan pembelajaran Teknik Melempar Bola. 


\section{DAFTAR PUSTAKA}

Arikunto, Suharsimi. 2002. Dasar dasar Evaluasi (edisi revisi) Jakarta: Rineka Cipta Aqib, 2009. Penelitian Tindakan Kelas. Bandung: Yrama Widya.

Depdiknas, 2002. Kegiatan Belajar Mengajar. Jakarta: Pusat Kurikulum Balitbang Depdiknas

Hamalik, Oemar, 2001 Proses Belajar Mengajar. Jakarta: Bumi Aksara

1990. Pengembangan Kurikulum (Dasar Dasar dan Perkembangannya) Bandung: CV. Mandar Maju.

Hamzah, 2009. Teori Motivasi dan Pengukukurannya (Analisis di Bidang Pendidikan) Jakarta: PT. Bumi Aksara

Lia, A. 2002. Memperaktekkan Cooveratif Leraning di ruang ruang kelas. Jakarta: PT. Gramedia

Madya Suwarsih, 2009. Teori dan Praktik Penelitian Tindakan Kelas (Action Reseach) Bandung: CV. Alfabeta. 